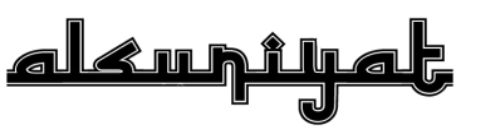

JURNAL PENELITIAN BAHASA, SASTRA, DAN

BUDAYA ARAB

P-ISSN: 2615-7241 | E-ISSN: 2721-480X // Vol. 3 No. 1 | 15-31

† https://ejournal.upi.edu/index.php/alsuniyat/index

\title{
KOMBINASI STRATEGI BERNYANYI DAN BERMAIN: UPAYA DALAM MENUMBUHKAN MOTIVASI MAHASISWA TADRIS BIOLOGI (TBG) DALAM PEMBELAJARAN BAHASA ARAB
}

\author{
Mahfuz Rizqi Mubarak, Ahmadi, Noor Amalina Audina \\ Institut Agama Islam Negeri Palangka Raya, Indonesia \\ E-mail: mahfuzrizqimubarak@iain-palangkaraya.ac.id
}

\begin{abstract}
:
This study aims to explore the process of lecturing Arabic by implementing a combination of singing and playing strategies. As for the main problems in this study are: (1) what is the process of implementing a combination of singing and playing strategies in Arabic lectures for Tadris Biology Study Program students? (2 how do their perceptions of the results of Arabic lectures by combining the two strategies?. This research uses a descriptive qualitative approach with triangulation techniques. The results of this study indicate that the implementation of a combination of singing and playing strategies uses the following steps: (1) The lecturer started the Arabic lecture by singing Arabic songs that the Lecturer got while still teaching Arabic at the Al-Azhar Pare Institute, Kediri, East Java, (2) The lecturer explained the theme of the material and the purpose of the lecture to be held, (3) The lecturer implemented the "Memory Game" which was adopted from the book "99 Games in Arabic Language Learning. Researchers also found that 80.6\% (29 students) and 19.4\% (7 students) of the 36 TBG study program students who participated in lectures gave very positive responses.
\end{abstract}

Keywords:

Arabic language; Singing strategy; Playing strategy

\begin{abstract}
Abstrak
Penelitian ini bertujuan untuk mengeksplorasi proses perkuliahan bahasa Arab dengan mengimplementasikan kombinasi strategi bernyanyi dan bermain. Adapun yang pokok permasalahan pada penelitian ini adalah: (1) bagaimana proses implementasi kombinasi strategi bernyanyi dan bermain dalam perkuliahan bahasa Arab mahasiswa Program Studi Tadris Biologi? (2) bagaimana persepsi mereka terhadap hasil perkuliahan bahasa Arab dengan mengkombinasikan kedua strategi tersebut?. Penelitian ini menggunakan pendekatan kualititif deskriptif dengan teknik triangulasi. Hasil dari penelitian ini menunjukkan bahwa impelementasi dari kombinasi strategi bernyanyi dan bermain menggunakan beberapa langkah berikut: (1) Dosen mengawali perkuliahan bahasa Arab dengan menyanyikan lagu-lagu bahasa Arab yang Dosen dapatkan ketika masih mengajar bahasa Arab di Lembaga Al-Azhar Pare, Kediri, Jawa Timur, (2) Dosen menjelaskan tema materi dan tujuan dari perkuliahan yang akan diselenggarakan, (3) Dosen mengimplementasikan "Permainan Ingatan" yang diadopsi dari buku "99 Permainan dalam Pembelajaran Bahasa Arab". Peneliti juga menemukan bahwa 80.6\% (29 mahasiswa) dan 19.4\% (7 mahasiswa) dari 36 mahasiswa prodi TBG yang berpartisipasi pada perkuliahan memberikan tanggapan yang sangat positif.
\end{abstract}

Kata Kunci:

Bahasa Arab; Srategi bernyanyi; Strategi bermain.

\section{PENDAHULUAN}

Kegiatan pembelajaran bahasa Arab berorientasi pada upaya pengembangan kemampuan peserta didik di bidang bahasa Arab serta keterampilan berbahasa baik secara lisan maupun tulisan. Dalam proses pembelajarannya, kreatifitas dari seorang pendidik menjadi tuntutan yang tak terelakkan mengingat keberhasilan suatu kegiatan pembelajaran tidak lepas dari peran seorang pendidik (Setiyawan, 2018). Maka dari itu, seorang pendidik 
harus kreatif dan inovatif dalam kegiatan pembelajaran baik pada aspek pemilihan pendekatan, metode, strategi, dan media.

Kreatifitas dipandang sebagai sebuah proses mental. Daya kreatifitas mengacu pada kemampuan berfikir yang lebih orisinal. Gagasan yang kreatif tidak akan muncul begitu saja, perlu adanya persiapan atau pembekalan sehingga hasil dari kreatifitas tersebut dapat menciptakan situasi yang baru, tidak monoton, dan menarik khususnya pada kegiatan pembelajaran (Effendi, 2016).

Sikap kreatifitas merupakan sebuah keterampilan masa depan yang dibutuhkan generasi milenial. Dalam lingkup pembelajaran, setiap pembelajaran (baik pendidik maupun peserta didik) harus kreatif dalam berinovasi sehingga hasil dari kreatifitas mereka kedepannya akan menjadi sebuah keuntungan di komunitas yang akan mereka geluti (Sari \& Mubaligh, 2019).

Beberapa tahun belakang ini, penelitian yang berorientasi pada kreatifitas seorang pendidik dalam pembelajaran bahasa Arab mulai banyak diminati. Berbagai macam pengembangan media dan strategi berbentuk permainan bahasa Arab mulai diimplementasikan para pendidik di sekolah jenjang dasar, menengah, bahkan perguruan tinggi. Hal ini diperlukan dalam rangka terwujudnya proses pembelajaran yang interaktif dan menyenangkan sebagai upaya menumbuhkan motivasi para peserta didik dalam belajar bahasa Arab (Ali, 2018).

Ada beberapa penelitian yang mengarah kepada hasil kreatifitas pendidik seperti pengembangan media MVR Abbas (Multimedia Virtual Reality Game) yang menampilkan animasi kreatif untuk meningkatkan keterampilan berbicara bahasa Arab (Kusumadewi dkk, 2019), pengembangan media pembelajaran kosa kata berbentuk video yang diberikan nama “Al-Muhtho" (Mufidah dkk, 2019), dan desain bahan ajar bahasa Arab dengan pendekatan hiwār untuk non-Arab (Jamil \& Agung, 2019).

Namun, kreatifitas pendidik dalam pembelajaran bahasa Arab tidak hanya terbatas pada aspek media dan bahan ajar saja. Kreatifitas dalam penerapan strategi pembelajaran juga menjadi hal yang perlu diperhatikan oleh seorang pendidik. Hal ini dibuktikkan dengan beberapa penelitian seperti penggunaan Student Teams Achievment Division (STAD) dalam pembelajaran bahasa Arab (Masyudi, 2019), strategi SCAMPER dalam keterampilan menulis bahasa Arab (Sari \& Mubaligh, 2019), dan penggunaan vlog dalam pembelajaran mahārah kalām (Mubarak dkk, 2020). 
Semua kreatifitas yang dihasilkan berbentuk media dan strategi dilakukan sebagai upaya para pendidik dalam menumbuhkan proses pembelajaran yang menyenangkan dan tidak monoton. Pembelajaran yang monoton akan berdampak buruk pada peserta didik seperti munculnya rasa bosan dan suasana jenuh sehingga tujuan pembelajaran yang dirumuskan tidak akan tercapai (Setyawan \& Fathoni, 2018).

Strategi penggunaan musik dan permainan juga menjadi salah satu hasil kreatifitas pendidik yang populer di kalangan para peneliti. Musik atau nyanyian dapat dijadikan alternatif pilihan para pendidik dalam pelaksanaan pembelajaran bahasa Arab. Mufidah dalam penelitiannya mengungkapkan bahwa pembelajaran bahasa Arab dengan bernyanyi dapat meningkatkan motivasi dan daya tarik belajar peserta didik terhadap bahasa Arab (Mufidah, 2019). Pendapat ini juga ditunjang oleh hasil penelitian lainnya yang mengungkapkan manfaat dari musik yaitu (1) membuat peserta didik rileks dan menghilangkan stres yang bisa menghambat pembelajaran, (2) merangsang kreatifitas peserta didik untuk memperoleh hasil yang lebih baik, (3) merangsang minat baca, keterampilan motorik, dan pembendaharaan kata peserta didik (Hasan, 2018).

Begitu juga penerapan permainan dalam proses pembelajaran bahasa Arab mampu memberikan iklim yang menyenangkan dalam proses kegiatan belajar mengajar (Sunarti, Ahmadi, \& Ilmi, 2017). Proses pembelajaran dengan strategi permainan akan membantu mahasiswa untuk menyerap informasi dan memahami materi dengan mudah serta mengingatnya dalam jangka panjang. Hal ini sangat logis mengingat semua aktifitas manusia di dunia ini tidak akan terlepas dari unsur bermain. Sebagaimana firman Allah dalam Al-Qur'an surah Al-An'am ayat 32 yang artinya “Kehidupan dunia ini adalah main-main dan senda gurau belaka ...". Maka dari itu, manusia baik laki-laki maupun perempuan, anak-anak maupun dewasa semuanya menyukai permainan (Latuconsina, 2018).

Salah satu dosen di IAIN Palangka Raya mengkombinasikan strategi bernyanyi dan bermain dalam pelaksanaan perkuliahan bahasa Arab untuk mahasiswa Program Studi Tadris Biologi (TBG) Semester Ganjil TA 2019/2020. Inisiatif kombinasi dua strategi ini didasari oleh beberapa alasan: (1) kurangnya motivasi mahasiswa TBG untuk belajar bahasa Arab. Bagi mereka, mata kuliah bahasa Arab hanya sebatas formalitas mata kuliah yang harus diambil di Fakultas Tarbiyah dan Ilmu Keguruan (FTIK) IAIN Palangka Raya dengan asumsi "yang penting lulus". Di sisi lain mahasiswa juga berasumsi bahwa mata kuliah bahasa Arab adalah mata kuliah yang "horor”. (2) dalam kurikulum MIPA, Mata Kuliah Bahasa Arab hanya mendapatkan 
satu kali dalam penyelenggarannya. (3) Mayoritas mahasiswa TBG berasal dari pendidikan umum seperti SD, SMP, \& SMA bahkan SMK yang di dalamnya tidaknya diajarkan mata pelajaran bahasa Arab. padahal, mata kuliah bahasa Arab sangat penting mengingat salah satu misi dari Program Studi TBG FTIK IAIN Palangka Raya adalah "Menyelenggarakan penelitian dan pengabdian kepada masyarakat tentang Pendidikan Biologi, ilmu Biologi, kajian Biotektologi Herbal serta integrasi keIslaman". Keislaman bersumber dari Al-Qur'an dan Hadis yang tertulis dengan bahasa Arab ("Visi dan Misi - Tadris Biologi,” n.d.).

Berdasarkan beberapa alasan tersebut, Dosen mata kuliah Bahasa Arab berinisiatif untuk mengimplementasikan dua kombinasi strategi tersebut dalam pelaksanaan perkuliahan bahasa Arab untuk mahasiswa prodi TBG. Dosen berharap bahwa implementasi dari keduanya dapat merubah persepsi mahasiswa prodi TBG mengenai "kehororan" bahasa Arab dan juga dapat menumbuhkan semangat mereka untuk mempelajari lebih jauh tentang bahasa Arab.

Dari beberapa fenomena yang telah disebutkan di atas, peneliti tertarik untuk meneliti lebih dalam mengenai perkuliahan bahasa Arab dengan mengkombinasikan strategi bernyanyi dan bermain yang diimplementasikan oleh dosen mata kuliah bahasa Arab untuk mahasiswa prodi TBG, Fakultas Tarbiyah dan Ilmu Keguruan (FTIK), IAIN PAlangka Raya. Peneliti berharap hasil penelitian ini memberikan wawasan baru terhadap para pendidik bahasa Arab secara umum dan khususnya para dosen pengampu mata kuliah Bahasa Arab untuk lebih kreatif dalam pelaksanaan Kegiatan Belajar Mengajar (KBM). Hal ini sangat diperlukan mengingat tidak semua peserta didik (siswa maupun mahasiswa) termotivasi dalam belajar bahasa Arab.

Oleh karena itu, peneliti merumuskan beberapa masalah sebagai berikut: (1) bagaimana proses implementasi strategi bernyanyi dan bermain dalam perkuliahan bahasa Arab mahasiswa prodi TBG? (2) bagaimana persepsi mahasiswa prodi TBG terhadap hasil implementasi perkuliahan dengan mengkombinasikan kedua strategi tersebut?.

Ada beberapa penelitian terdanulu yang dapat mendukung penelitian ini: Ali dalam penelitiannya yang berjudul "Outbond as The Alternative Method to Have Fun Arabic Learning” yang menghimpun hasil-hasil penelitian pembelajaran menggunakan metode outbond untuk Pendidikan Anak Usia Dini (PAUD) dan beberapa siswa SMA. Ali mengungkapkan bahwa "Outbound learning method provides a solution by bringing about a nature-based learning concept to improve students' interest, motivation, and achievement in Arabic" yang bermakna bahwa permainan outbond yang diimplementasikan dalam pembelajaran bahasa Arab menjadi 
solusi alternatif untuk proses pembelajaran yang menyenangkan serta mampu meningkatkan minat, motivasi, dan prestasi terhadap peserta didik (Ali, 2018).

Simarmata \& Indriani dalam penelitiannya yang berjudul "The Use of a Relay Race Game to Increase Grade V Students/Motivation in Learning English in One of Elementary Schools in Karawaci" mengungkapkan bahwa permainan lari estafet (Relay Race Game) dapat meningkatkan motivasi peserta didik sekolah dasar (SD) dalam belajar bahasa Inggris (Simarmata \& Indriani, 2016).

Terakhir, Ula \& Isbah dalam penelitiannya yang berjudul “'Amaliyah Ta'lim Hifdh AlMufradat Bi Wasithah Al-Ughniyah Li Tarjamah Kutub At-Turats" mengungkapkan bahwa media musik dapat menciptakan suasana belajar yang menyenangkan serta mampu memberikan kemudahan para santriwati Ponpes Masyariqul Anwar, Babakan, Ciwaringin, Cirebon untuk menghafal kosa kata sehingga membantu mereka untuk memahami makna yang tertulis di kitāb al-turāts (klasik) (Ula \& Isbah, 2017).

Dari beberapa hasil penelitian sebelumnya, dapat disimpulkan bahwa belum ada penelitian yang mengkombinasikan dua strategi seperti strategi bernyanyi dan bermain dalam pelaksanaan pembelajaran. Penelitian terdahulu juga hanya membatasi objek, penelitian pada pelaksanaan pembelajaran pada peserta didik di tingkat PAUD, SD, SMA, dan pondok pesantren. Sedangkan dalam penelitian ini, objek penelitiannya adalah peserta didik di tingkat Perguruan Tinggi (mahasiswa).

\section{METODE}

Pada penelitian ini, peneliti menggunakan penelitian kualitatif deskriptif. Penelitian kualitatif bertujuan untuk memperoleh informasi atau gambaran hal yang akan diteliti (situasi sosial) yang meliputi aspek tempat (place), pelaku (actor), dan aktifitas (acitivity) yang berinteraksi secara sinergis. Situasi sosial pada ranah pendidikan seperti ruang kelas, pendidik maupun peserta didik, serta aktifitas proses pembelajaran (Sugiyono, 2015). Deskriptif berfungsi sebagai pemecah masalah penelitian dengan mendeskripsikan atau menggambarkan situasi sosial yang akan diteliti.

Dalam penelitian ini, peneliti bermaksud untuk mendeskripsikan beberapa hal berikut: (1) implementasi perkuliahan bahasa Arab terhadap mahasiswa prodi TBG dengan mengkombinasikan dua strategi yaitu strategi bernyanyi dan bermain, (2) persepsi mahasiswa 
prodi TBG mengenai hasil perkuliahan bahasa Arab dengan mengimplementasikan dua kombinasi strategi tersebut.

Sedangkan teknik pengumpulan data pada penelitian ini menggunakan tiga teknik yang dikenal dengan istilah "triangulasi" yaitu observasi, wawancara, dan dokumentasi. (1) Observasi digunakan dengan pengamatan secara cermat dan nyata tentang proses impelementasi perkuliahan bahasa Arab dengan kombinasi antara strategi bernyanyi dan bermain di kelas. (2) Wawancara digunakan untuk memperoleh informasi secara rinci mengenai langkah-langkah dalam mengimplementasikan dua kombinasi strategi tersebut dalam perkuliahan bahasa Arab. (3) Dokumentasi berupa angket yang disusun melalui google form untuk disebarkan ke seluruh mahasiswa prodi TBG. Penyebaran angket ini digunakan untuk mengetahui persepsi para mahasiswa mengenai hasil proses perkuliahan dengan menggunakan kombinasi dua strategi tersebut.

Gambar 1: Teknik pengumpulan data menggunakan triangulasi

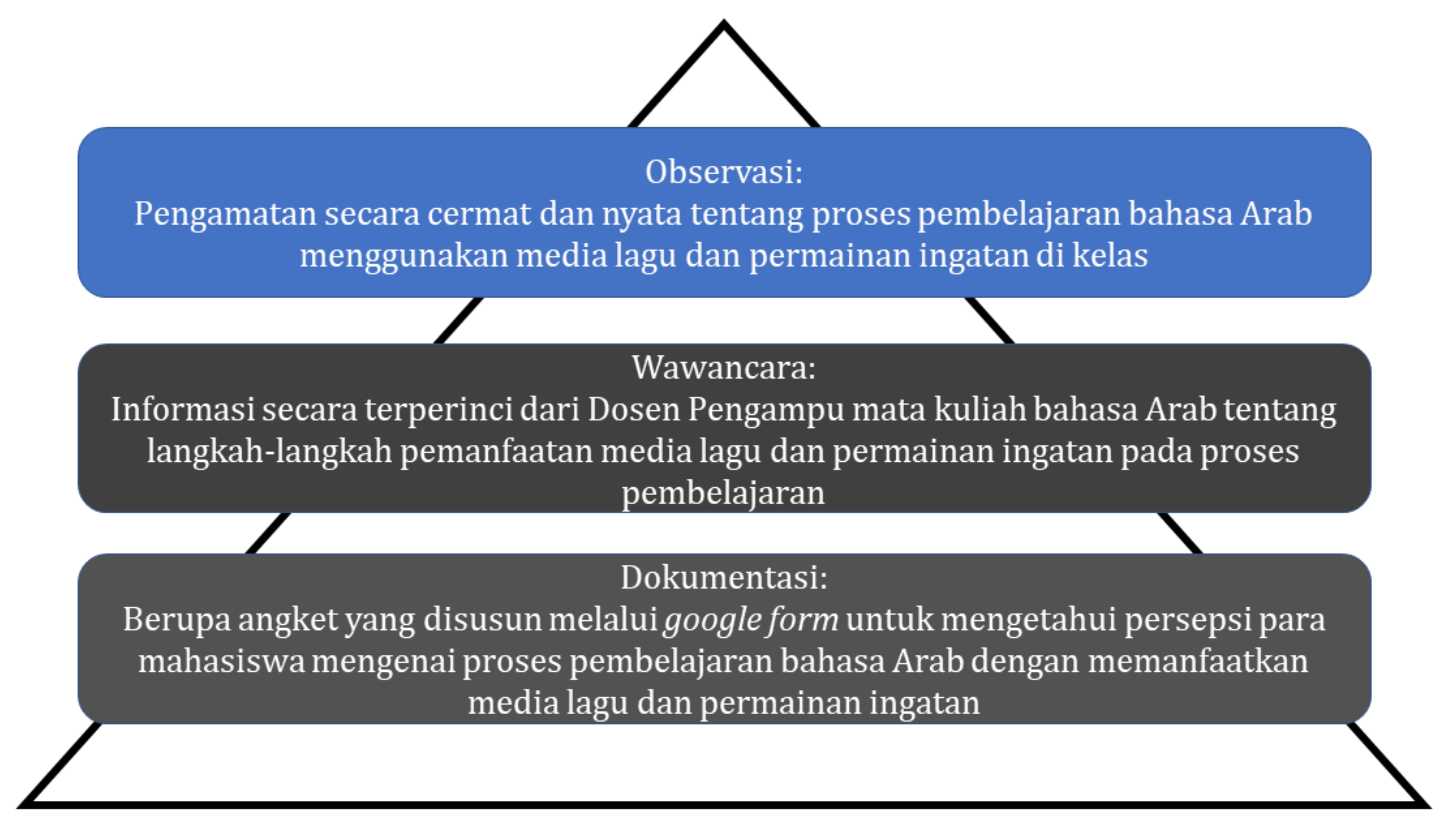

Teknik analisis data pada penelitian ini menggunakan model Miles dan Huberman yang mencakup tiga aktifitas analisis data yaitu reduksi data (data reduction), penyajian data (data display), dan kesimpulan/verifikasi (conclusion drawing/verification) (Miles \& Huberman, 2009).

Pada penelitian ini, reduksi data berfungsi untuk memilah data mentah yang dihasilkan dari observasi, wawancara, dan dokumentasi sesuai dengan kebutuhan penelitian. Setelah 
proses reduksi, peneliti akan menyajikan data sesuai dengan fokus yang akan diteliti yaitu impelementasi kombinasi antara strategi bernyanyi dan bermain dalam perkuliahan bahasa Arab terhadap mahasiswa TBG. Peneliti juga melakukan penarikan kesimpulan terhadap hasil reduksi, dan penyajian data hasil penelitian serta mengaitkannya dengan hasil penelitian sebelumnya sehingga menghasilkan temuan baru.

Gambar 2: Teknik analisis data menggunakan model Miles dan Huberman

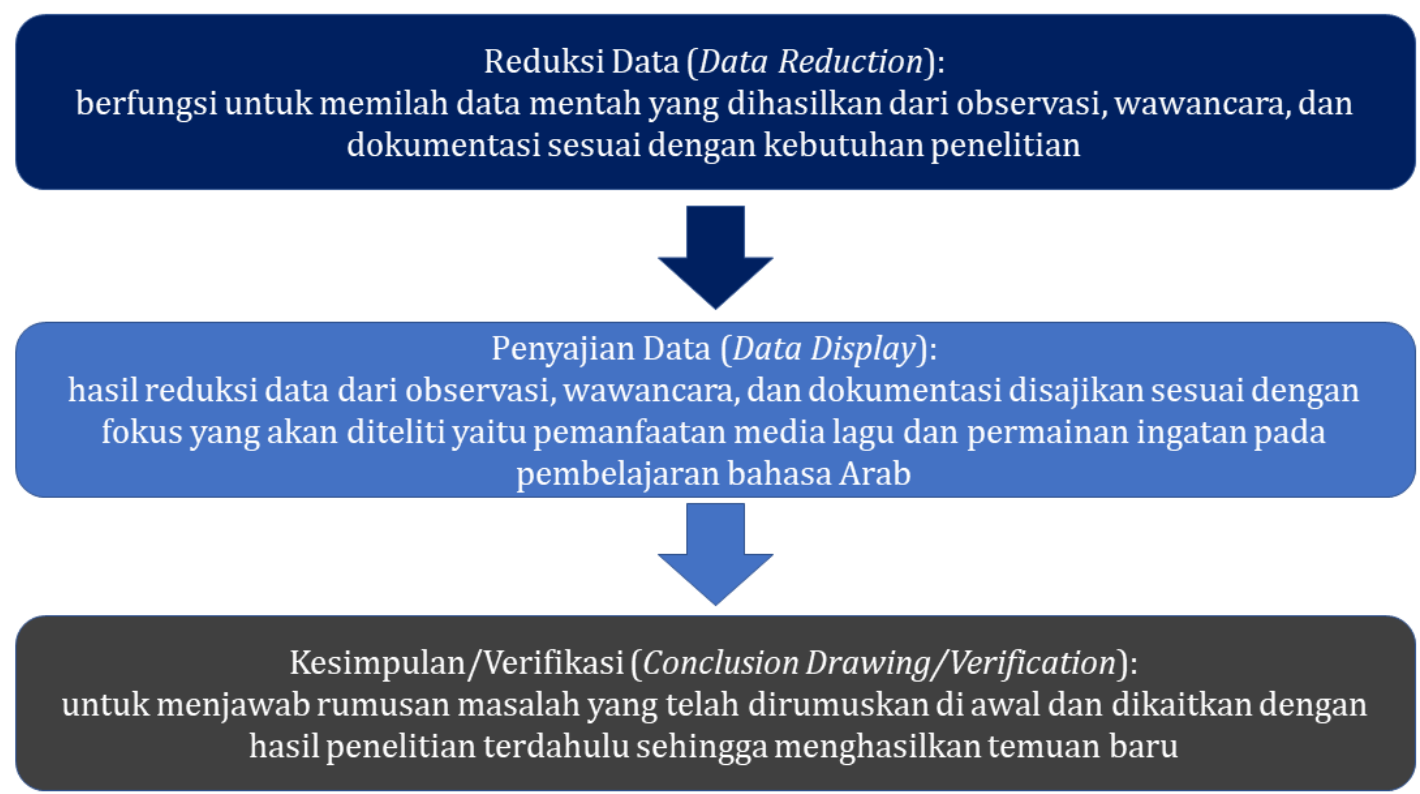

\section{HASIL DAN PEMBAHASAN}

Berdasarkan paparan data dari hasil obervasi kelas, wawancara terhadap dosen, dan dokumentasi berupa angket yang dibagikan kepada mahasiswa prodi TBG, Peneliti akan menjabarkan hasil penelitian berdasarkan beberapa topik berikut: alasan pengkombinasian dua strategi yaitu antara strategi bernyanyi dan bermain dalam pelaksanaan perkuliahan bahasa Arab, langkah-langkah impelementasi dari kombinasi kedua strategi, dan persepsi mahasiswa mengenai hasil perkuliahan bahasa Arab dengan mengimplementasikan kombinasi kedua strategi tersebut.

\section{Alasan Penggunaan Kombinasi Strategi Bernyanyi dan Bermain pada Perkuliahan Bahasa Arab}

Sebagaimana yang telah disebutkan di atas, penggunaan strategi ini didasarkan beberapa alasan yaitu (1) kurangnya motivasi mahasiswa prodi TBG untuk belajar bahasa Arab, (2) 
jumlah jam perkuliahan bahasa Arab yang kurang memadai, (3) dan mayoritas mahasiswa prodi TBG yang tidak memiliki dasar dalam pelajaran bahasa Arab. beberapa alasan ini menuntut dosen pengampu mata kuliah bahasa Arab untuk mencari solusi dalam mewujudkan proses perkuliahan yang interaktif dan tidak membosankan yang dapat menumbuhkan motivasi mahasiswa untuk mengikuti perkuliahan bahasa Arab. Hal ini juga selaras dengan hasil penelitian Chandra, dkk bahwa hilangnya motivasi dalam belajar berimplikasi pada ketidak tercapainya dari tujuan pembelajaran tersebut (Chandra dkk, 2016).

Pengkombinasian dari dua strategi antara strategi bernyanyi dan bermain dilandasi oleh beberapa alasan berikut: (1) aktiftas bernyanyi telah menjadi salah satu sumber hiburan yang populer di kalangan mahasiswa. Dosen juga tidak jarang melihat mahasiswa bernyanyi sambil mendengarkan musik dengan menggunakan headset sembari menunggu kedatangan dosen di dalam kelas. Pendapat ini juga selaras dengan penelitian Akbary, dkk yang menyebutkan bahwa "Listening to music has always been a popular source of entertainment among youth" yaitu mendengarkan musik selalu menjadi sumber hiburan yang populer di kalangan remaja (Akbary dkk, 2018), bahkan Daniel Levitin sebagaimana dikutip oleh Ollerhead (2019) menambahkan bahwa musik menjadi alat yang lebih kuat dari bahasa untuk membangkitkan gairah emosional manusia (Ollerhead, 2019),

(2) Dosen juga meyakini bahwa proses perkuliahan yang disajikan dalam bentuk permainan dapat meningkatkan antusias mereka dalam belajar. Pendapat ini juga selaras dengan hasil penelitian Roshayanti, dkk yang berpendapat bahwa proses pembelajaran yang dikemas dalam bentuk permainan akan membuat peserta didik menikmati setiap proses dari pembelajaran tersebut (Roshayanti dkk, 2014).

(3) Dari dua kombinasi antara strategi bernyanyi dan bermain diharapkan dapat melahirkan proses perkuliahan yang di dalamnya tedapat pola hubungan yang kuat antara dosen dan mahasiswa tanpa adanya paksaan atau tekanan, dan juga dapat melahirkan lingkungan belajar yang menarik dibarengi dengan perasaan gembira, semangat dan penuh konsentrasi.

Dari beberapa alasan tersebut dapat disimpulkan bahwa ada dua alasan utama dosen untuk berinisiatif menggunakan kombinasi dua strategi (bernyanyi dan bermain). Alasan pertama berasal dari problematika yang dihadapi mahasiswa seperti: (1) tidak adanya motivasi mahasiswa untuk belajar bahasa Arab, (2) Waktu belajar bahasa Arab yang kurang memadai, (3) dan mayoritas mahasiswa yang tidak memiliki latar belakang dalam pelajaran bahasa Arab. 
Alasan kedua berkiatan dengan kombinasi dua strategi yang diharapkan dapat menumbuhkan suasana perkuliahan yang aktif dan menyenangkan sehingga dapat meningkatkan motivasi dan semangat mahasiswa prodi TBG untuk belajar bahasa Arab.

\section{Langkah-langkah Implementasi Kombinasi Strategi Bernyanyi dan Bermain pada Perkuliahan Bahasa Arab}

Dalam proses impelementasinya, dosen sebagai fasilitator utama memiliki peran yang sangat penting dalam kesuksesan pelaksanaan perkuliahan dengan mengkombinasikan kedua strategi tersebut. Berikut beberapa langkah yang digunakan oleh dosen dalam mengimplementasikan strategi bernyanyi dan bermain pada perkuliahan bahasa Arab:

Pertama, Dosen mengawali perkuliahan dengan menyebarkan teks lirik nyanyian bahasa Arab yang akan dinyanyikan bersama-sama di kelas. Adapun lirik nyanyian tersebut didapatkan oleh dosen yang sebelumnya berstatus sebagai salah satu pengajar bahasa Arab di Lembaga Al-Azhar Pare, Kediri, Jawa Timur. Ada beberapa judul lagu yang digunakan ketika ingin memulai perkuliahan, yakni: العربية (Bahasa Arab), هُنَا نَفْرَحُ هُنَالَكَ نَفْرَحُ (di sini Senang di sana

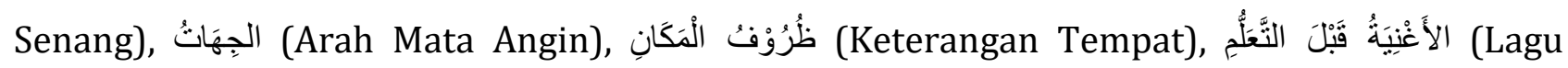
Sebelum Belajar), dan إِذَا أَنْتَ سَعْيْنُ (jika kamu senang).

\begin{tabular}{|c|c|}
\hline & \\
\hline Bahasa Arab adalah Bahasa Al-Qur'an & آلْعَرَبَّةة لُغَةُة الْقُرْآنِ \\
\hline Begitu juga bahasa yang ada di syurga & كَمَاَ هِيَ لُغَةِ فِي الجِنَانِ \\
\hline Diharapkan agar setiap guru dan murid & يُرْجَى مِنْ كُلِّ أُسْتَاذِ وَطَالِبٍ \\
\hline Berbicara dengan bahasa Arab & 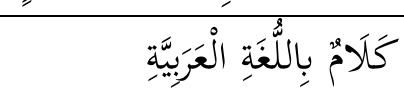 \\
\hline Berbicara untuk mendapatkan cinta & 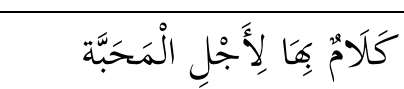 \\
\hline Kepada Rasulullah, Nabi pembawa rahmat & 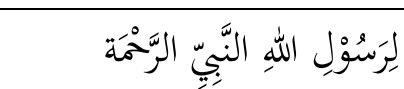 \\
\hline Barang siapa berbicara dengan niat ibadah & مَنْ تَكَكَّمَ ينِيَّةِة الْعِبَادَة \\
\hline $\begin{array}{l}\text { Maka dia akan mendapatkan kebahagiaan } \\
\text { dari Allah }\end{array}$ & تََصََّلَ ِِنَ اللهِ السَّعَادَة \\
\hline
\end{tabular}

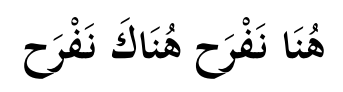

Di sini Senang di sana Senang

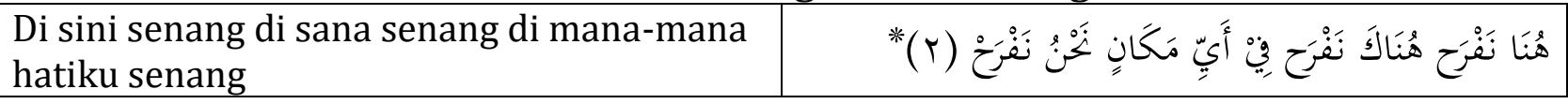




\begin{tabular}{|l|l|}
\hline La la la la la la ... & $\ldots$ \\
\hline
\end{tabular}

*diulang sebanyak dua kali

$$
\text { الجِهَاتُ }
$$

\section{Arah Mata Angin}

\begin{tabular}{|c|c|}
\hline Utara, Timur Laut, Timur, Tenggara & 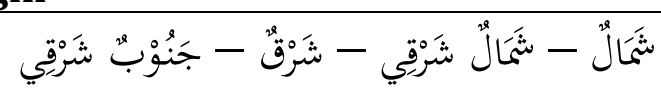 \\
\hline Selatan, Barat daya, Barat, Barat Laut & جَنُوْبٌ - جَنُوْبٌ غَرْبِي - غَرْبٌ - شَمَالٌ غَرْبِي \\
\hline
\end{tabular}

\section{ظُرُوْفُ الْمَكَانِ}

\section{Keterangan Tempat}

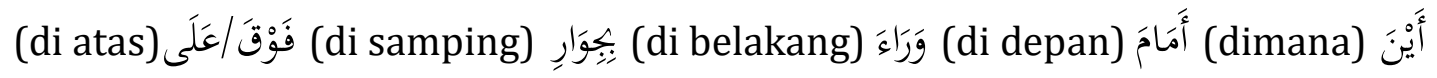

(di sini dan di sana) هُنَا، هُنَاكَتَ (itu di bawah)

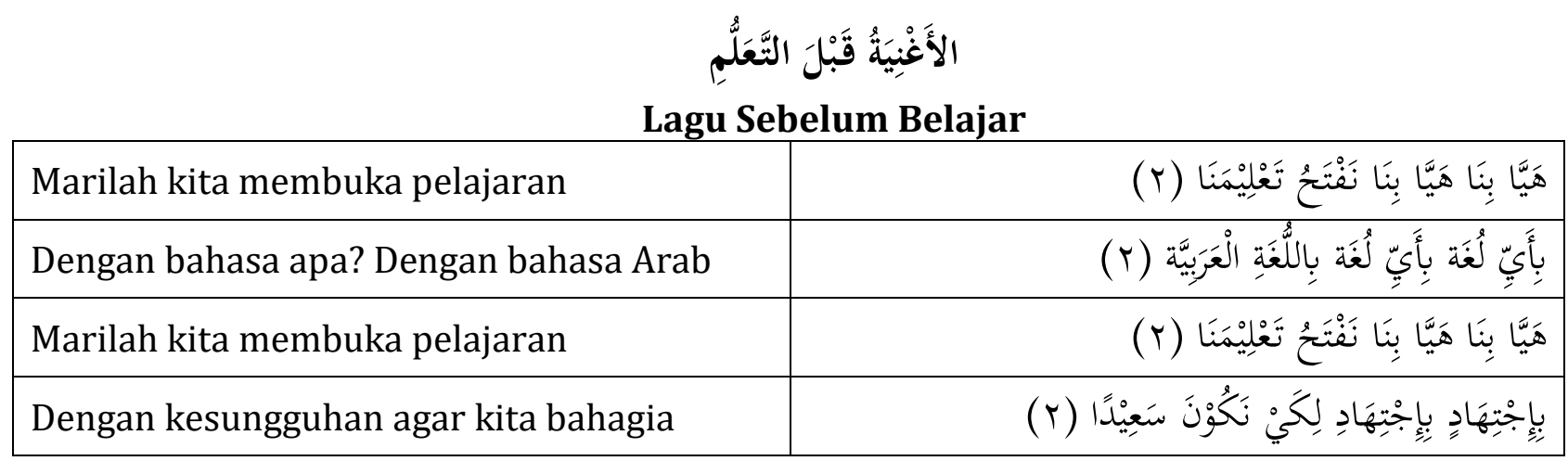

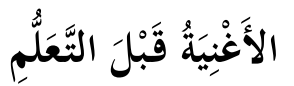

Lagu Sebelum Belajar

\begin{tabular}{|c|c|}
\hline Marilah kita membuka pelajaran & هَيَّا بِنَا هَيَّا بِنَا نَفْتَعْ تَعْلْيْمَنَا (r) \\
\hline Dengan bahasa apa? Dengan bahasa Arab & 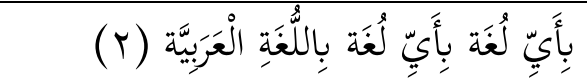 \\
\hline Marilah kita membuka pelajaran & هَيَّا بِنَا هَيَّا بِنَا نَفْتَحُ تَعْعِيْمَنَا (Y) \\
\hline Dengan kesungguhan agar kita bahagia & بإِجْتِهَادِ بإِجْتِهَادِ لِكَيْ نَكُوْنَ سَعِيْدًا (r) \\
\hline
\end{tabular}

$$
\text { إذذا أَنْتَ سَعِيْدُ }
$$

Jika Kau Suka Hati

Jika kau suka hati tepuk tangan (2x)

إِذَا كُنْتَ سَعِيْدًا صَفِقِق يَدَيْكَ (r) 


\begin{tabular}{|c|c|}
\hline Jika kau suka hati dan hatimu gembira & إِذَا كُنْتَ سَعِيْدًا وَقََلْبُكَكَ مَسْرُوْرًا \\
\hline Jika kau suka hati tepuk tangan & إِذَا كُنْتَ سَعِيْدًا صَفِّقِ يَدَيْك \\
\hline Jika kau suka hati hentak kaki (2x) & إِذَا كُنْتَ سَعِيْدًا دُقَّ رِجْجَلَنْك (r) \\
\hline Jika kau suka hati dan hatimu gembira & إِذَا كُنْتَ سَعِيْدًا وَقَلْبُكَكَ مَسْرُوْرًا \\
\hline Jika kau suka hati hentak kaki & إِذَا كُنْتَ سَعِيْدًا دُقَّ رِجْجَيْكُك \\
\hline Jika kau suka hati ucap semangat (2x) & إِذَا كُنْتَ سَعِيْدَ قُلْ حَمَاسَة (r) \\
\hline Jika kau suka hati dan hatimu gembira & إِذَا كُنْتَ سَعْيْدًا وَقَلْبُعَكَ مَسْرُورًَا \\
\hline Jika kau suka hati ucap semangat & إِذَا كُنْتَ سَعِيْدَ قُلْ حَمَاسَة \\
\hline
\end{tabular}

Dosen berharap bahwa Lagu-lagu bahasa Arab yang dinyanyikan di setiap awal perkuliahan dapat menumbuhkan motivasi mahasiswa prodi TBG dalam belajar bahasa Arab. Mahasiswa juga dapat memahami arti dari setiap lagu yang dinyanyikan mengingat naskah lirik lagu yang dibagikan dosen sudah dilengkapi dengan terjemahan.

Kedua, setelah menyanyikan lagu-lagu bahasa Arab, dosen menjelaskan tema materi yang akan dipelajari pada pertemuan tersebut. Tema materi yang digunakan disesuaikan dengan ruang lingkup dari prodi TBG yang bermuara pada pendidikan biologi dan ilmu biologi. Maka dari itu, dosen memutuskan untuk mengambil tema tentang "أعضاء الجسم" (Anggota Tubuh). Dosen juga menjelaskan bahwa tujuan dari perkuliahan bahasa Arab dengan tema ini dapat memberikan wawasan kepada mereka tentang kosakata bahasa Arab yang berkaitan dengan anggota tubuh manusia serta mempraktikkan kosakata tersebut ke dalam sebuah kalimat sederhana. Dosen menyederhanakan tujuan dari perkuliahan bahasa Arab tersebut mengingat mayoritas mahasiswa prodi TBG berasal dari sekolah-sekolah umum yang di dalamnya tidak diajarkan sedikit pun tentang bahasa Arab.

Ketiga, pada tahap ini, Dosen menjelaskan strategi permainan yang akan digunakan dalam perkuliahan bahasa Arab. Permainan tersebut dinamakan dengan "Permainan Ingatan" yang diadopsi dari sebuah buku yang berjudul "99 Permainan dalam Pembelajaran Bahasa Arab" (Zuhdy \& Fatawi, 2015). Pada Implementasinya, langkah-langkah dari permainan ini sebenarnya mirip dengan permainan bisik berantai yang mengandalkan ingatan dari mahasiswa yang diperdengarkan secara berbisik oleh mahasiswa lainnya (Uliyah \& Isnawati, 2019). Ada beberapa langkah yang digunakan oleh dosen dalam mengimplementasikan permainan ini, yakni: (1) Dosen membagi 36 mahasiswa prodi TBG menjadi 4 kelompok dan 
berbaris berbanjar ke belakang. Dosen juga menghindari terjadinya percampuran antara lakilaki dan perempuan mengingat permainan ini menggunakan cara berbisik antar mahasiswa sehingga rentan terjadinya hal-hal yang melanggar syariat Islam. (2) Dosen menunjuk satu mahasiswa dari masing-masing kelompok untuk maju ke depan dan harus mengingat sebuah kalimat yang diperdengarkan dosen secara lisan. Ada beberapa kalimat bahasa Arab yang telah disiapkan dosen sesuai dengan tema yang digunakan pada perkuliahan tersebut (أعضاء الجسم), yakni:

\begin{tabular}{|c|c|}
\hline Aku memiliki dua tangan & لمليْ يَدَانِ \\
\hline Di atas kepala ada rambut & ى لى الرَأسِِ شَعْرُ \\
\hline Aku bernafas menggunakan hidung & سُُ لِالْلَأَنْفِ \\
\hline Aku mendengar menggunakan telinga & 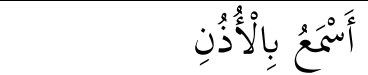 \\
\hline Cucilah tangan sebelum makan & أَغَسِلِل الْيَدَ قَبْلَ الْأَكْلِ \\
\hline Aku mencuci wajah ketika wudhu & 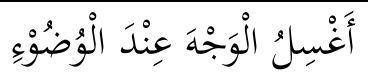 \\
\hline Aku membersihkan gigi sebelum tidur & أُنَظِّفُْ الََْسْنَانَ قَبْبَ النَّوْْر \\
\hline
\end{tabular}

(3) Mahasiswa yang telah diperdengarkan kalimat bahasa Arab oleh dosen harus membisikkannya lagi ke seluruh mahasiswa yang ada di kelompoknya masing-masing. (4) Mahasiswa yang terakhir harus menuliskan hasil kalimat yang telah dia dengar dan mengumpulkannya ke Dosen. (5) Dosen mengevaluasi hasil akhir dari masing-masing kelompok dan memberikan satu point kepada kelompok yang berhasil menuliskan kalimat dengan benar. Langkah-langkah ini dapat diulang sesuai dengan jumlah kalimat yang telah disediakan. Dosen juga memberikan reward kepada kelompok yang paling banyak dalam menuliskan kalimat secara tepat.

Dari beberapa penjelasan berikut, dapat disimpulkan bahwa langkah-langkah impelementasi kombinasi strategi bernyanyi dan bermain pada perkuliahan bahasa Arab tediri dari: (1) mengawali perkuliahan dengan menyanyikan lagu-lagu bahasa Arab yang dosen dapatkan ketika berstatus sebagai pengajar bahasa Arab di Lembaga Al-Azhar Pare, Kediri, Jawa Timur. beberapa judul lagu yang digunakan, yakni: العربية نَفْرَحُ هُنَالكَ نَفْرَحُ (Bahasa Arab), (di sini Senang di sana Senang), الجِهَاتُ (Arah Mata Angin), طُرُوْفُ الََْكَانِ (Keterangan Tempat),

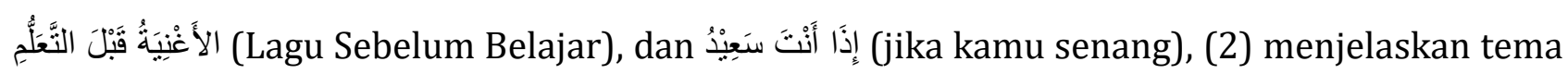
materi dan tujuan dari perkuliahan yang akan diselenggarakan, (3) mengimplementasikan 
"Permainan Ingatan" dengan beberapa langkah seperti pembagian kelompok, memperdengarkan sebuah kalimat bahasa Arab ke masing-masing mahasiswa, mengumpulkan hasil kalimat yang telah diperdengarkan secara tertulis kepada dosen, dan mengevaluasi serta memberikan reward kepada kelompok yang paling banyak menuliskan kalimat secara tepat.

Sebagaimana yang telah disebutkan sebelumnya bahwa langkah-langkah implementasi dari "Permainan Ingatan" ini diadopsi dari buku "99 Permainan dalam Pembelajaran Bahasa Arab" (Zuhdy \& Fatawi, 2015) yang memiliki kemiripan pada aspek implementasinya dengan “Permainan Bisik Berantai” (Uliyah \& Isnawati, 2019).

\section{Persepsi Mahasiswa Prodi TBG Mengenai Kombinasi Strategi Bernyanyi dan Bermain di Perkuliahan Bahasa Arab}

Selain dari dosen, peneliti juga mengumpulkan hasil angket yang disebarkan via google form untuk mengumpulkan tanggapan mahasiswa prodi TBG tentang pelaksanaan perkuliahan bahasa Arab dengan mengkombinasikan strategi bernyanyi dan bermain. peneliti mengumpulkan hasil tanggapan sebanyak 36 mahasiswa dengan diagram tanggapan sebagai berikut:

Gambar 3: diagram hasil tanggapan angket mahasiswa 36 tanggapan

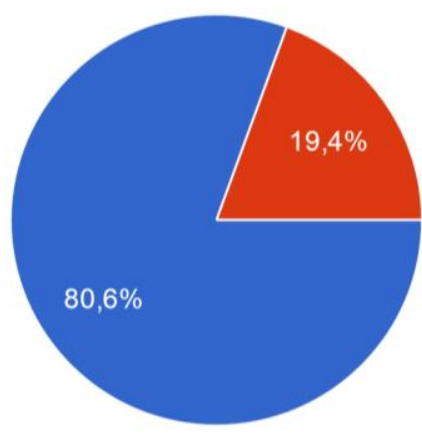

Sangat Setuju

Setuju

Tidak Setuju

Sangat Tidak Setuju

Dari hasil diagram tersebut dapat disimpulkan bahwa mayoritas mahasiswa prodi TBG memberikan tanggapan Sangat Setuju sebanyak 80.6\% (29 Mahasiswa), tanggapan Setuju sebanyak 19.4\% (7 Mahasiswa), dan tidak ada satupun mahasiswa yang memberikan tanggapan tidak setuju atau bahkan sangat tidak setuju. Hal ini membuktikkan bahwa seluruh mahasiswa prodi TBG sangat menyukai perkuliahan bahasa Arab dengan mengkombinasikan kedua strategi tersebut. 
Peneliti menyimpulkan beberapa manfaat yang didapatkan melalui hasil tanggapan mahasiswa prodi TBG setelah mengikuti pelaksanaan perkuliahan dengan mengimplementasikan kombinasi strategi bernyanyi dan bermain sebagai berikut:

Pertama, memberikan kemudahan terhadap mahasiswa untuk memahami materi yang diajarkan. Mahasiswa juga mudah mengingat kosakata-kosakata bahasa Arab yang dikemas dalam bentuk sebuah nyanyian dan permainan.

Kedua, suasana perkuliahan menjadi sangat aktif dan tidak membosankan. Hal ini membuat mahasiswa termotivasi untuk belajar dan menjadi stimulus mahasiswa untuk memperbanyak hafalan kosakata setiap harinya.

Ketiga, permainan yang diimplementasikan berimplikasi pada peningkatan kerjasama dan kepercayaan satu sama lain serta melatih kefokusan mereka terhadap materi yang disajikan dengan bentuk permainan.

Keempat, merubah sugesti mahasiswa yang selama ini menganggap bahasa Arab sebagai pelajaran yang "horor" menjadi pelajaran yang "menyenangkan".

Dari beberapa manfaat tersebut, dapat disimpulkan bahwa tujuan dosen dalam mengimplementasikan kombinasi strategi bernyanyi dan bermain dapat dikatakan berhasil dan efektif. Dosen berhasil merubah asumsi mahasiswa prodi TBG yang awalnya berpendapat bahwa mata kuliah bahasa Arab merupakan mata kuliah yang "horor" menjadi mata kuliah yang "menyenangkan". Dosen juga berhasil menumbuhkan motivasi mahasiswa prodi TBG untuk mempelajari bahasa Arab. Hal ini dapat dilihat dari antusias mereka untuk menghafal kosakata bahasa Arab.

Namun, implementasi dari kedua strategi ini juga tidak lepas dari kekurangan seperti ruangan kelas yang tidak mendukung dalam strategi bermain, ada beberapa mahasiswa yang tidak menyukai permainan, dan juga beberapa mahasiswa cenderung memanfaatkan keaktifan mahasiswa lainnya sehingga tidak ikut aktif dan menyerahkan seluruh bagiannya ke mahasiswa yang aktif tersebut.

\section{SIMPULAN}

Dari hasil penelitian ini, peneliti menyimpulkan bahwa langkah-langkah implementasi kombinasi strategi bernyanyi dan bermain pada perkuliahan bahasa Arab mahasiswa prodi TBG sebagai berikut: (1) Mengawali perkuliahan dengan menyanyikan lagu-lagu bahasa Arab yang berjudul: العربية (Bahasa Arab), هُنَاً نَفْرَحُ هُنَالكَ نَفْرَحُ (di sini Senang di sana Senang), الجِهَاتُ (Arah

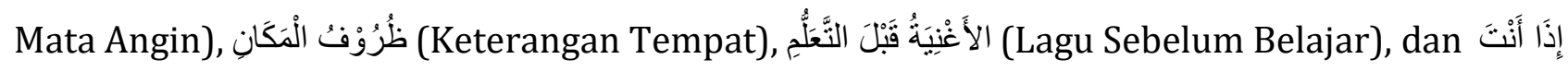


سَعِيْدُ (jika kamu senang). (2) Menjelaskan tema materi dan tujuan dari perkuliahan yang akan diselenggarakan, (3) mengimplementasikan "Permainan Ingatan" dengan beberapa langkah seperti pembagian kelompok, memperdengarkan sebuah kalimat bahasa Arab ke masingmasing mahasiswa, mengumpulkan hasil kalimat yang telah diperdengarkan secara tertulis kepada dosen, dan mengevaluasi serta memberikan reward kepada kelompok yang paling banyak menuliskan kalimat secara tepat. Peneliti juga menemukan bahwa dari 36 mahasiswa prodi TBG yang mengikuti perkuliahan sebanyak 80.6\% (29 Mahasiswa) memberikan tanggapan sangat setuju, dan 19.4\% (7 mahasiswa) memberikan tanggapan setuju. Tidak ada satupun mahasiswa yang memberikan tanggapan tidak setuju atau bahkan sangat tidak setuju. Mayoritas tanggapan positif yang diberikan mahasiswa ini menunjukkan bahwa kombinasi dua strategi yang diimplementasikan oleh dosen terbukti efektif untuk meningkatkan motivasi mahasiswa prodi TBG untuk belajar bahasa Arab.

\section{DAFTAR PUSTAKA}

Akbary, M., Shahriari, H., \& Hosseini Fatemi, A. (2018). The value of song lyrics for teaching and learning English phrasal verbs: A corpus investigation of four music genres. Innovation in Language Learning and Teaching, 12(4), 344-356. https://doi.org/10.1080/17501229.2016.1216121

Ali, J. (2018). Outbound as The Alternative Method to Have Fun Arabic Learning. ALSINATUNA, 3(2), 244. https://doi.org/10.28918/alsinatuna.v3i2.1276

Chandra, Y., Yusuf, A. M., \& Jaya, Y. (2016). Motivasi Belajar Siswa Madrsah Aliyah dalam Mengikuti Mata Pelajaran Bahasa Arab dan Implikasinya dalam Layanan Bimbingan dan Konseling (Studi pada Siswa Madrasah Aliyah Negeri 1 Sungai Penuh yang Berasal dari Sekolah Menengah Pertama). Konselor, 5(2), 83-92-92. https://doi.org/10.24036/02016526544-0-00

Effendi, M. (2016). Integrasi Pembelajaran Active Learning dan Internet-Based Learning dalam Meningkatkan Keaktifan dan Kreativitas Belajar. Nadwa, 7(2), 283. https://doi.org/10.21580/nw.2013.7.2.563

Hasan, H. (2018). Keterampilan Mengajar Bahasa Arab Materi Istima Menggunakan Media Lagu. Al Qalam: Jurnal Ilmiah Keagamaan Dan Kemasyarakatan, O(0), 127-148. https://doi.org/10.35931/aq.v0i0.7 
Jamil, H., \& Agung, N. (2019). Designing The Arabic Learning Book Based on The Hiwar Approach for Non-Arabic Education Program at Muhammadiyah Islamic University of Sinjai (ar). Al-Ta'rib : Jurnal Ilmiah Program Studi Pendidikan Bahasa Arab IAIN Palangka Raya, 7(2), 97-110. https://doi.org/10.23971/altarib.v7i2.1561

Kusumadewi, N., Nurizki, A. F., Pratama, A. B., \& Zukhaira, Z. (2019). MVR ABBAS: Multimedia Virtual Reality Game Berbicara Bahasa Arab Untuk Siswa Jenjang Menengah Pertama. Arabi : Journal of Arabic Studies, 4(1), 44-54. https://doi.org/10.24865/ajas.v4i1.136

Latuconsina, S. N. (2018). Efektivitas Permainan Bahasa Arab dalam Meningkatkan Kemampuan Membaca Mahasiswa Program Studi Pendidikan Bahasa Arab. Arabi: Journal of Arabic Studies, 3(2), 145. https://doi.org/10.24865/ajas.v3i2.99

Masyudi, M. (2019). Strategi Pembelajaran Kooperatif Model Student Teams Achievement Division (STAD) Terhadap Hasil Belajar Bahasa Arab. Tawazun, 11(2), 247-262. https://doi.org/10.32832/tawazun.v11i2.1672

Miles, M. B., \& Huberman, M. (2009). Analisis Data Kualitatif. Jakarta: UI Press.

Mubarak, M. R., Wahdah, N., Ilmiani, A. M., \& Hamidah, H. (2020). Penggunaan Vlog Dalam Pembelajaran Mahārah Kalām. Al Mi'yar: Jurnal Ilmiah Pembelajaran Bahasa Arab dan Kebahasaaraban, 3(1), 109-126. https://doi.org/10.35931/am.v3i1.209

Mufidah, N. (2019). Fun Arabic Teaching with Song Media For Primary Schools/Pengajaran Bahasa Arab Menyenangkan Dengan Media Lagu Untuk Madrasah Ibtidaiyah. AlMudarris: Journal of Education, 2(2), 166-185-185. https://doi.org/10.32478/almudarris.v2i2.277

Mufidah, N., Salamah, U., Muthoharoh, I., \& Islamy, M. I. (2019). Hybrid Learning Dalam Pembelajaran Kosa Kata Bahasa Arab Pada Anak Berbantuan Media Al-Mutho. AlMudarris, 2(1), 40-52. https://doi.org/10.32478/al-mudarris.v2i1.227

Ollerhead, S. (2019). Teaching across semiotic modes with multilingual learners: Translanguaging in an Australian classroom. Language and Education, 33(2), 106-122. https://doi.org/10.1080/09500782.2018.1516780

Roshayanti, F., Hayat, S., \& Artharina, P. (2014). Penerapan Pendidikan Karakter Dalam Pembelajaran Sains Melalui Model Pembelajaran Berbasis Permainan Tradisional Engklek. Prosiding Seminar Nasional Entrepreneurship. FPMIPA Universitas PGRI Semarang, 5. 
Sari, R. R., \& Mubaligh, A. (2019). Scamper Sebagai Strategi Menulis Kreatif Bahasa Arab Abad 2. Journal of Arabic Studies, 10.

Setiyawan, A. (2018). Problematika Keragaman Latar Belakang Pendidikan Mahasiswa Dan Kebijakan Program Pembelajaran Bahasa Arab. Arabiyat: Jurnal Pendidikan Bahasa Arab dan Kebahasaaraban, 5(2), 195-213. https://doi.org/10.15408/a.v5i2.6803

Setyawan, C. E., \& Fathoni, M. (2018). Desain Konsep Pembelajaran Bahasa Arab Dengan Model Quantum Teaching. Al-Ta'rib : Jurnal Ilmiah Program Studi Pendidikan Bahasa Arab IAIN Palangka Raya, 6(1), 60-79. https://doi.org/10.23971/altarib.v6i1.1010

Simarmata, E., \& Indriani, S. (2016). The Use of a Relay Race Game to Increase Grade V Students' Motivation in Learning English in an Elementary School in Karawaci. Polyglot: Jurnal Ilmiah, 12(1), 82-89. https://doi.org/10.19166/pji.v12i1.384

Sugiyono. (2015). Metode Penelitian Pendidikan. Bandung: Alfabeta.

Sunarti, S., Ahmadi, A., \& Ilmi, Z. (2017). Tatsir Al La’b Al Tarbawi Fii Ta'liim Al Lughoh AL Arobiyah Li Al Fashl AL Saabi' Bi AL Madrosah AL Mutawasithoh Al Hukumiyah Al Namudzajiyah Baalankarayaa. Al-Ta'rib : Jurnal Ilmiah Program Studi Pendidikan Bahasa Arab IAIN Palangka Raya, 5(1), 55-71. https://doi.org/10.23971/altarib.v5i1.768

Ula, M., \& Isbah, F. (2017). 'Amaliyyah Ta'lim Hifdh Al-Mufradat Bi Wasithah Al-Ughniyah Li Tarjamah Kutub At-Turats. ALSINATUNA, 2(1), 69-88. https://doi.org/10.28918/alsinatuna.v2i1.828

Uliyah, A., \& Isnawati, Z. (2019). Metode Permainan Edukatif Dalam Pembelajaran Bahasa Arab. Shaut al Arabiyyah, 7(1), 31-43. https://doi.org/10.24252/saa.v1i1.9375

Visi dan Misi - Tadris Biologi. (n.d.). Retrieved February 19, 2020, from http://biologi.ftik.iainpalangkaraya.ac.id/visi-dan-misi/

Zuhdy, H., \& Fatawi, M. F. (2015). 99 permainan dalam pembelajaran bahasa Arab. Retrieved from http://repository.uin-malang.ac.id/658/ 